\title{
312 土木技術者として東日本大震災合同調査報告・機械編から考えること

\author{
A thought from stand point as Civil Engineer about "Report on the Great East Japan \\ Earthquake Disaster, Mechanical Engineering Volume.
}

\author{
○打田 憲生（ミネルヴァ技術事務所）
}

\begin{abstract}
Norio UCHIDA, Minerva Engineering Office , 121-1 Hagioka-cho, Nagoya, 464-0805 Japan
\end{abstract}
Key Words: Report on the Great East Japan Earthquake Disaster, A thought from stand point as Civil Engineer

\section{1. はじめに}

東日本大震災をうけて、科学技術・学術審議会 学術分科 会は「リスク社会の克服と知的社会の成熟に向けた人文学及 び社会科学の振興について」という委員会報告を 2012 年 7 月 25 日に公表している。これは、人文学及び社会科学の振 興に関する委員会（主査・樺山紘一）によるものであるが、 科学技術のあり方に関しても貴重な見解を示している。 論旨は「東日本大震災は我が国の社会に甚大は被害をもたら したばかりでなく、これとともにあった科学技術や学術に対 しても、未曽有の衝撃と反省をもたらすものであった。地震 とそれに起因する巨大な災禍の下にある人類社会に対して、 ぞのような対応の方途がありうるのであろうか」と、科学技 術や学術のあり方への見直しの必要を提起している。そして、

「科学技術や学術は本来において、知的社会の推進に向けて 注力すべきものであり、そこに重大な責任を負っている」と している。つづけて「はたして、社会に安寧と幸福に貢献す べき科学技術や学術として、自然の大きな営みの中で発生し た災害や今後にあって憂慮される災害がある中で、どのよう に人間・社会等に向き合い研究活動を構想することが可能で あろうか」と根本的な議論の喚起を提起している。

今回の大震災に際し、科学技術分野では鋭意調查・研究の 途上にあるが、いまだ包括的な調査報告を眼にしていない。 東日本大震災による甚大な被害は、とりわけ自然災害は人の 住むところに顕著に現れるものである。その災害としてたち 現れる様々な現象を、科学技術の分野では例えば工学分野を 総動員して分野横断的に把握するが知識体系がまだないこ とによるのであろう。今回の大震災は、様々な分野の隙間の 弱点を衝くかたちで、あるいは科学工学的知見の不在のあり かを明示するかのような現象を示しているように思われる。 科学技術と学術の間、科学と技術の間、学術の細分化された ジャンルの間にある課題を浮き彫りにすることとなった。

全く同様の認識から、科学技術や学術の振興を図る上での、 同委員会報告の 3 つの視点での提言概要を明記しておく。

（1）諸学の密接な連携と総合性の必要性に関して、急速に 進む専門化を優先させて細分化に陥り、知の統合や分野をこ えた総合性への視点の欠落があったこと。

(2) 学術への要請と社会貢献の内容について、今般の災害 や社会の高度化・複雑化を背景に、研究や社会的機能の発揮 が改めて期待されていること。

（3）グローバル化と国際学術空間について としている。 そして、当面講ずべき推進方策の一つとして、先導的な共同 研究の対象として「領域開拓」、「実社会対応」、「グローバル 展開」を目指す研究を推進し、共同研究の課題を設定すると している。これは、人文科学だけでなく、科学技術の今後あ るべき姿への示唆であると受け取れるメッセージでもある。

2. 東日本大震災合同調査報告・機械編の発刊 2013.7 .31

東日本大震災の発災以降、各専門家集団はそれぞれの専門 分野に関する調查活動を一斉に開始し、研究が進められつつ ある。報告によると、これらの調査・研究活動は、日本学術
会議、日本工学会、その他の学協会と連携を図りつつ行われ、 成果は 8 学会加なる合同調查報告書編集委員会に集約さ れる。そして、その先発として東日本大震災合同調査報告・ 機械編が日本機械学会から 2013 年 7 月 31 日に刊行された。 今後 2017 年までに、膨大な報告書の刊行が予定されている。 2.1 合同調査報告書編集委員会の「序」・基本姿勢の表明

ここでは、日本機械学会としてではなく、より包括的立場 での調査・研究にたいする姿勢を明らかにしている。「人や 社会は遠くで起きたこと、遠い昔に起きたことなど、体験し ていないことへの想いは薄く、人々は今を生き活動すること に懸命である。しかし、専門家が遠い過去から未来へと繰り 返される自然や地球の動きを忘れることは許されない。そし て、地震や津波に対して安全で人々が安心して暮らすことの できる社会を目指して、研究・開発を進め、この調査・研究 の報告を生かし、次に起こるかもしれない大地震・津波によ って、同じ災害が起こらないことを祈る」と科学技術の専門 家の立場を代表して社会に明確に表明されている。刊行予定 からは最後に包括的提言がなされる構想のようである。

\section{2 日本機械学会からの視点「まえがき」より}

日本機械学会では、震災直後の 2011 年 4 月 8 日に、タス クフォース/東日本大震災調査・提言分科会合同会合で調査 の基本方針が定められ、この地震と震災の特徵を、(1)地震の 規模が大きいこと、(2)引き続き起こった津波の規模が巨大で あったこと、(3)被害地域が広範で、被害者数が多いこと、(4) 原発事故と放射性物質の環境への放出という新たな事態へ の対応を求められていること、と認識された。そして、長期 的視点からの提言を検討するため、主として機械工学の観点 から被害状況の調査行い、機械工学に携わる技術者及び研究 者として反省すべき点、学ぶべき点を整理すること、将来に 向けて改善すべき点は何か、日本機械学会として何ができる か、といった視点から活動を行うことが決定された。

また、今回の被害規模はあまりにも大きく、機械工学の分 野に限っても、全貌を網羅的に調査することは困難であり、 他の学協会の報告書を参照し、既に機械学会で行っている

「阪神・淡路大震災」および「中越沖地震」における調查資 料を参考にする、としている。さらに、原発関連とそれ以外 に、また被害状況は地震力によるものと、津波によるものを 分けて整理することとしている。しかし、地震と津波の災害 への関与は重要であり、機械学会の範疇ではないとながらも その特徴に関しては地震学の専門家による解説を参考にす るとう共同作業がなされている。そして、システムインテグ レーションの視点を盛込み、今回の大震災という経験をふま えて、機械工学の研究者・技術者はどのような教訓を得るの かという、大震災に学ぶ機械工学のあり方に関する大局的提 言があってしかるべきと考える、調査・研究が進められた。 3. 大震災に学ぶ機械工学の在り方

長期的な視点からの提言内容は「福島原発事故の教訓から 学ぶ工学の原点と社会的使命一安心・安全社会の構築」と定 めて日本工学会会長を主査とする検討会で別途に議論され 
ており、機械学会では、以下の提言がなされている。

I : 大規模システムのシステム・インテグレーション

III : デザインベースの考え方、“Beyond”への対応

III：リスクコミュニケーションの課題

$\mathrm{IV}:$ 継続的調査と規格・基準への展望

これらの課題は、より一般的に工学に携わる者に突きつけ られた大きな課題であるが、機械学会あるいは機械工学の立 場から、より高い位置から今回の大震災の総括が試みられ、 貴重な知見を導き出す研究成果をあげている。

3.1 大規模システムのシステム・インテグレーション

原子力発電設備などの大規模システムにおいては、科学お よび工学の多様な知識が統合されているが、大規模災害に晒 された場合、個々の専門知の隙間に弱点が存在することを確 認している。これらに対して、優れた専門家の存在では解決 できない問題であり、これを克服するためのシステム・イン テグレーションの方法論の確立が必要であるとしている。そ のためには、従来の学会による「認識の科学」偏重から「設 計の科学」のための方法論の開発を、現場のモノづくり技術 者をまきこんで実行するという新しい考えを提起している。

3.2 デザインベースの考え方、“Beyond”への対応

安全目標である設計基準 (想定値) は、人工物の機能と安 全性それにコストのバランスを考えて、線引きする政策的判 断で決定されてきた。しかし、想定值は、社会が「受け入れ 可能なリスク」として許容するレベルで決定されなければな らない。そして、専門家/研究者は「絶対安全」はあり得な いことを社会に説明すること必要であり、専門家の役割は、 想定を超える事態での事故または被害を正しく分析してお くこと、これに対処する方法を準備しておくこととする。さ らに、想定值は専門家のみの判断で決定すべきではないとし ており、従来の通念から大きく踏み込んだ提言となっている。 3.3 リスクコミュニケーションの課題

社会は、人工物がつくられる根拠となっている科学技術の 基本原理をブラックボックスとして受け入れ、その理解は専 門家任せになっている。しかし、人工物はその基本仕様を決 めるにあたって、必ず外力などの「想定值」が定められ、少 ない頻度ながら外力が想定值を超える場合も起こり得る。 人々が安全・安心を求める時、基本的に事故が起きないこと

「絶対安全」を暗黙裡に求めているのであり、専門家は安全 の中身をブラックボックスにたままで安全・安心を保証して はならない、と指摘しその上で、リスクを正しく予測してそ れに対処する技術（リスクマネジメント）と、リスクを正し く社会に発信して社会の了解を受ける技術（リスクコミュニ ケーション)、この二つを身につける必要を提起している。

\section{4 継続的調査と規格・基準への展望}

一方、調査結果からは過去の地震被害を教訓とした対策を 講じられていた場合、相当の被害の軽減、防止が図られたこ とが評価されている。只の上で、今回の教訓や調査・研究成 果をマニュアルや規格・基準に早急に反映することが提起さ れている。そして ASME 的発想として、自らが関係する規格・ 基準は自ら参加して作成していくという意識改革の必要性 と、基準等作成には実際の技術の現場をよく知り、見識もあ る民間の技術者が議論をリードしていくことは、実用的で有 用な基準を作成する上で重要なこと、産業界等の当事者が作 成する基準は公平性の観点等から問題があるとする認識は 誤ったものである、という極めて重要な指摘がなされている。

\section{4. 専門分野WG からの提言の意義}

つぎに、専門分野ごとの WG による、より詳細は調査・研 究をもとにした提言とその意義について整理する。これは多 岐に亘っており、ここではそのうちの数項目を挙げる。

\section{1 地震との連成災害の防止}

今回の地震災害では地盤変状に伴う基礎、埋設管等の被害
が多く見られた。今後は、建屋と地盤との相対変形が想定さ れる箇所にはフレキシブル配管を設置し、段差が生じると地 震後の作業に支障の出るような構内道路や港湾施設の機器 基礎などでは、液状化対策を行なうなど、地盤変状に伴う減 災の具体的方策や施工箘所の詳細を提起している。

\section{2 津波被害メカニズムの理解に基づく設計・対策}

これは地震学と工学の隙間への言及として、津波の被害メ カ二ズムは複雑であり、防潮堤のような津波防御構造物にた よって、津波から機器や機械設備の被害を防ぐことは困難で ある。まず、津波被害メカニズムを正確に理解することが第 一で、これは機械学会の主要課題（自前の知見が必須）であ ると認識し、その上で構造物や機器・機械設備類を津波被害 からどう守るのか、そのためにどう設計するべきか、どんな 対策をとるべきか、と考える筋道をマニュアル化している。 4.3 真のリスク概念に基づく安全向上

福島第一の事故原因は設計想定を超える津波に襲われた こと、全電源器失し炬心冷却機能が失われたことにあり、設 計想定を超える津波への対処が行われず、原子力安全の根幹 である深層防護が完全でなかったこと、意味ではリスク管理 が適切ではなかった、と明確に分析し指摘している。その上 で、リスク概念導入の意義を、規制側、事業者とも正しく理 解して、不要な安全管理の排除と、真に必要な部分への資源 集中を推奨するルール化が必要であると提言している。

\section{4 望ましい規制の在り方について}

これまでの安全規制の傾向として、設計認証や溶接検査の 詳細まで国が直接確認してきたことを指摘し、これが現場に お沙制の過剩を生み、真の安全に関する高い視点からの 検討の不足を招いてきたと指摘している。その一方で、科学 的・技術的検討の局面において、過度の中立性要求は、冷静 な議論を妨げるものであり、民間規格の活用と第三者認証の 活用を推進する機械学会の従来の主張を改めて示している。 4.5. 事業者の安全責任について

本来、規制要求や規制基準は、安全に関する最低限の要求 事項である、とした上で「事業者はプラント安全の直接的責 任を負う立場から規制要求や規制基準は必要最低条件であ る（それを満たすことは当然で、それだけではいけない）こ との認識を持つこと、継続的に安全を追求する意識を徹底す るべきである」という事業者の独立責任という態度を明示。 4.6 耐震設計について

今回の地震を含め大きな地震を受けた場合、全てのプラン 卜は安全停止し、安全上重要な構造物、系統、機器の損傷や 機能喪失などの報告はなかった。その意味では現行耐震設計 は機能したと評価している。しかし、断層の評価など設計地 震動の策定には大きな不確かさが含まれ、設計地震動を上回 る地震に対する残余のリスク評価が重要になる、としている。 5. おわりに

東日本大震災合同調査報告 ・機械編の発刊は画期的な成果 であり、今後引き続き発刊が予定されている8 学会からの迅 速な報告に期待したい。しかし、ここで指摘したいことは、 最初に揭げた科学技術・学術審議会 学術分科会の委員会報 告での指摘に対する回答への未達である。即ち、8学会の境 界、学会内の専門境界領域の弱点の克服への包括的展望の中 にこそ、実は防災・減災の主要な要件が秘められることを多 くの関係者は知悉しているのではないか。しかし、そのアプ ローチは安易ではなく、同時に今日のわが国の科学技術の力 の限界に底通する問題を含んでいるようにも思われる。

\section{6. 参考文献}

1) 東日本大震災合同調査報告・機械編 日本機械学会 2013

2) 東日本大震災合同調查報告・共通編 1 土木学会 2014

3) 東日本大震災合同調查報告 - 共通編 2 地盤工学会 2014

4) 東日本大震災合同調査報告・共通編 3 地盤工学会 2014 